Selcuk Journal of Agriculture and Food Sciences

http://sjafs.selcuk.edu.tr/sjafs/index

Review Article

\section{SJAFS}

(2019) 33 (3), 260-266

e-ISSN: $2458-8377$

DOI:10.15316/SJAFS.2019.186

\title{
Dust Transportation and Pastures
}

\author{
Ramazan ACAR ${ }^{1}$, Mevlüt DEMİRYÜREK ${ }^{2}$ \\ ${ }^{1}$ Selçuk University, Faculty of Agriculture, Department of Field Crops, Konya, Turkey \\ ${ }^{2}$ Agriculture and Rural Development Support Institution Konya Provincila Coordination Unit, Konya, Turkey
}

\begin{tabular}{l}
\hline ARTICLE INFO \\
\hline Article history: \\
Received date: 20.05 .2019 \\
Accepted date: 13.09 .2019 \\
\hline Edited by: \\
Ummuhan ÇETIN KARACA; Selçuk \\
University, Turkey \\
Reviewed by: \\
Orhan DENGİ; Ondokuz Mayıs Uni- \\
versity, Turkey \\
Şükrü DURSUN; Konya Technical \\
University, Turkey \\
\hline Keywords: \\
Dust transport \\
Pasture \\
Wind erosion \\
Grazing animal
\end{tabular}

\section{Introduction}

Dust is defined as solid particules which are suspended in the air in a specific time. Dust that dimensions are range from 1 and 100 micrometersare particules formed as a results of erosion, degredation, granulation and burning from the organic an inorganic materials. Existince of mineral dust is arouse from climatical conditions, plant vegatation, erosion, construction, agriculture, mining, industrial works, degragated pastures and deforested areas (Anonymous 2016). The amount of dust formation is mainly depended on 3 factors which are cohesion of material allows the particles to be held in mass, secondly dimension of particles related to transportation and third one is air current that is wind speed enables to dust movement and controls of decreasing of wind speed impede transportation. It is importand to take incremental measures for first 2 factors but reducing measures for third in factor in formation and transportation of dust. Any one or more of these three properties of the dust can be changed to minimize the amount of dust (Anonymous 2012).

Dust transport is important for ecosystems (land, marine ecosystems) and human activities in the World. The main causes of dust transportation are drought and

\footnotetext{
*Corresponding author email: racar@selcuk.edu.tr
}

desertification. Dust transportation has negative effects on climate, health and productivity. Dust rises to the upper layers of the atmosphere and travel long distances. Turkey, as it is close to the desert and existence of latitude value, is exposed to the dust storm by means of wind storm. In recent years, an average of 20 million tons of dust is deposited into our country as wet or dry. Studies carried out to date have shown that desert dusts are more effective especially in transition seasons. In the spring and autumn, it is considered as the period when desert dust increases its effect. The region most affected by dust storms is in Southeast Anatolia Region, especially our settlements close to Syria and Iraq border (Figure 6). According to the model study conducted by Tegenand Lacis in 1996, the atmospheric lifespan of the mineral dusts, defined as 0.1-10 $\mu \mathrm{m}$ grain size, are given as follows according to their dimensions. The particle size was measured in $\mu \mathrm{m}: 0.15$, $0.25,0.40,0.80,1.50,2.5,5.0,8.0$, and Atm. the duration of life as hour is $231,229,225,219,179,126,67$, 28. Figure 1 shows the effect of wind erosion according to particle size (Figure 1) (Anonymous 2016).

In the Anatolian region of Turkey, the reason of dust mobility is often the results of wind erosion. Therefore, measures to prevent wind erosion in steppe areas dominated by the continental climate will also reduce dust transportation. 


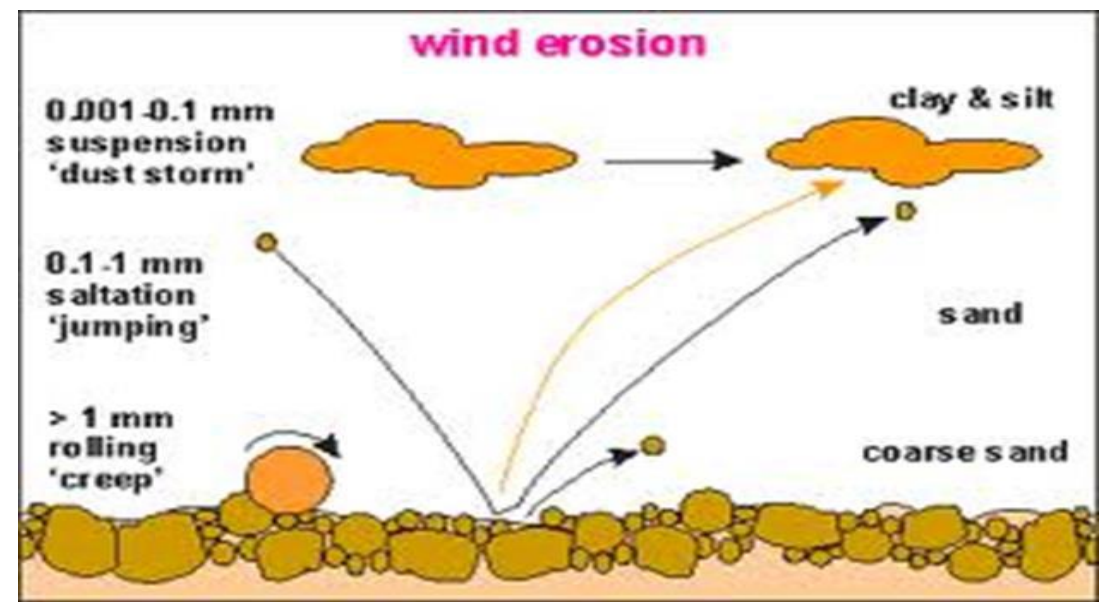

Figure 1

Effect of wind erosion on particle size (Anthoni 2000).

\section{Causes, Effects and Solutions of Dust in Pasture Areas}

The shortest way to reduce the dust transportation occurring in pasture conditions is to reduce dust formation and transportation, in other words, reducing wind erosion and sensible area to erosion. We can examine the dust transportation in the pastures in three ways as damage to plants and animals and the environment. We can also collect these in the following headings;

1- The damages to the plant: a) damages to plant development/growth and productivity b) damages to plant quality

2- Damage to grazing animals a) health hazards of animals b) damages related to their output c) damages related to their manegement and administration

3- Environmental hazards a) damages as pollutants b) damages due to accumulation c) damages in terms of living standards

In the semi-arid (step) regions of our country, the cultivation of large areas for field crop cultivation causes the impoverishment of the lands and the increase the erosion. The pasture grasses, which were resistant to harsh natural conditions, although they had low yields, kept the lands in place. With the removal of these weeds to make the field, the pasture land under heavy pressure of grazing has become sensible to fly away with vigorous and fierce winds. It is stated in the book, describing the history of the Karapinar district in which the most wind erosion calamity occure in Turkey (Gündüz 1980), Nomadic Turkmen conducted large scale of the animal husbandry in Karapınar-
Hotamıs plain and in the yearbook of Rumi dated 1300, it was mentioned and praised about animal breeding such as horses, sheep and goats in Karapinar-Hotamış plain, but in these breeding in 1953-59 and 1960-63 was a great blow with the distributions of land to the landless citizens. Because of this wrong applications the erosion was increased in pastures and cultivation areas by using inappropriate farming siystem. Historical realities justify us in this respecty. It is importand to use these places as a absolute pasture classified as absolute pasture areas. In such places, ensuring an appropriate transformation by reclamation will help to solve the problem from the beginning. Especially the priority can be applied in arid and inefficient production areas (Acar and Dursun 2010).

In addition to the dust damages caused by carrying strong wind, it is stated that strong wind causes evaporation of water in the soil, decreasing in retaining peculiarities of water to soil particles, drying of soil surface by warming, decreasing the growth rate of plants in insufficient water conditions and increasing the pests in arid land conditions (Avc1 et al 2015).

As shown in Figure 2, whether the soil surface is covered with plants or not is related to the formation and efficiency of the wind erosion which causes the both water and dust transportation. In addition, the structure of the soil is also important in this regard. The soil structure with the most abrasion/structure characteristics was stated to be sandy sand> heavy clay> fine sandy loam $>$ excess dust (Demiryürek et al 2007). The damage caused by wind erosion is inversely proportional to the amount of vegetation on the surface. 


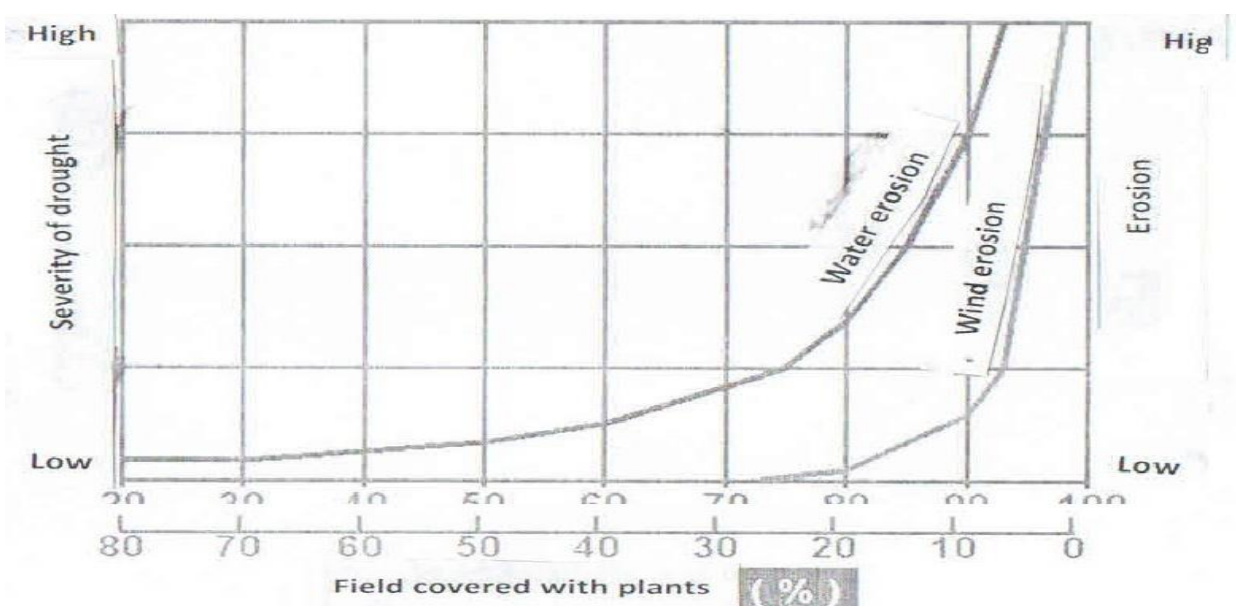

Figure 2

Table 2

The relationship between plant and erosion in the pastures (Altın et al 2011).

The amount of sediment in sediment-holding containers at different elevations in the Karapinar wind erosion site (between Ort.2000-2005) (Demiryürek et al 2007).

\begin{tabular}{lcccccc}
\hline Areas & $\begin{array}{c}\text { Depth } \\
\mathrm{cm}\end{array}$ & $\begin{array}{c}\text { Sand } \\
\%\end{array}$ & $\begin{array}{c}\text { Clay } \\
\%\end{array}$ & $\begin{array}{c}\text { Silt } \\
\%\end{array}$ & $\begin{array}{c}\text { Organic } \\
\text { Matter } \\
\%\end{array}$ & $\begin{array}{c}<0.42 \mathrm{~mm} \\
\text { Dry agr. } \\
\%\end{array}$ \\
\hline \multirow{4}{*}{ Pasture } & $0-2.5$ & 82.43 & 3.47 & 14.11 & 0.78 & 83.1 \\
& $2.5-5.0$ & 90.49 & 3.47 & 6.04 & 0.81 & 80.0 \\
& $5.0-10.0$ & 86.45 & 7.50 & 6.05 & 0.63 & 68.6 \\
& $10.0-25.0$ & 86.43 & 9.53 & 4.04 & 0.75 & 48.8 \\
Field & $25.0-40.0$ & 80.35 & 11.56 & 8.08 & 0.45 & 38.4 \\
area & $0-2.5$ & 61.19 & 26.61 & 12.20 & 1.55 & 52.2 \\
& $2.5-5.0$ & 59.10 & 26.64 & 14.26 & 1.41 & 43.7 \\
& $5.0-10.0$ & 59.06 & 26.67 & 14.27 & 1.21 & 40.6 \\
\end{tabular}

Table 3

The total amount of dust transported from pasture and cultivated area (Demiryürek et al 2007).

\begin{tabular}{ccccc}
\hline $\begin{array}{c}\text { Altitute } \\
\mathrm{Cm}\end{array}$ & \multicolumn{2}{c}{$\begin{array}{c}\text { Pastures } \\
\text { (17 İst. avr.) }\end{array}$} & \multicolumn{2}{c}{$\begin{array}{c}\text { Field areas } \\
(10 \text { İst. avr. })\end{array}$} \\
& $\mathrm{g}$ & $\%$ & $\mathrm{~g}$ & $\%$ \\
\hline 10 & 0.232 & 58.10 & 0.421 & 44.70 \\
20 & 0.076 & 19.10 & 0.224 & 23.80 \\
30 & 0.038 & 9.60 & 0.126 & 13.40 \\
45 & 0.024 & 6.10 & 0.074 & 7.80 \\
65 & 0.013 & 3.30 & 0.042 & 4.50 \\
90 & 0.009 & 2.30 & 0.029 & 3.10 \\
120 & 0.005 & 1.20 & 0.016 & 1.70 \\
150 & 0.001 & 0.40 & 0.008 & 0.90 \\
Total & 0.398 & 100 & 0.940 & 100 \\
\hline
\end{tabular}

As seen in Figure 2 and Table 2, it is clearly seen the relation of occuring of wind erosion or the amount of dust transportation when the land is covered with vegetation and in Table 3, the total amount of dust transported from pasture areas $(0.398 \mathrm{~g})$ is much less than the amount of land in the cultivated area $(0.940 \mathrm{~g})$.

The Factors affecting wind erosion;
A- Natural factors: 1-Climate (precipitation, heat, humidity, wind) 2- Soil 3-Vegetation

B-Human factors (Abali et al 1986).

In Central Anatolia (annual average 300-350 mm rainfall), due to excessive evaporation in late June, it is stated that absorption by dry and hot air of whole humidity in the soil, unable to use water on the top layers of soil, especially dominating of wind in summer months were the main reason of distressing conditions of life (Birand 1968).

Pasture reclamation is one of the biggest problems of our country. Plants to be selected in pasture reclamation should be able to adapt to the region and use plants belonging to different families in the mixtures. If the herbaceous plants for the mixture for covering soil in the pasture reclamation to be selected, herbaceous plants should be large, if possible, the tall, rhizome and stolon forming should be considered more (Akalan and Dogan 1988).Especially, in pastures where wind erosion occurs, both live and artificial wind breakers which minimize the drying and carrier damages of winds should be applied in such a way that they do not obstruct grazing and that the existing pastureland protection. When selecting live wind breakers, firstly shrubs, semi-shrubs or wood species should be selected, which are fast growing and resistant to drought 
plants that do not harm animals and that can also partially graze and extend the grazing period (Mücevher et al 2016). There should also have some facilitatives functions such as grazing, shading, etc. for grazing animals. In other words, it should be considered together with pasture improvement and erosion prevention in such places. Pastures formed with a balanced combination of fringe rooted species (grainy species), pilerooted species (especially legumes), fodder plants and tree species can be defined as ideal pastures in arid and semi-arid climatic zones (Acar 2017). As a result of the destruction in a significant part of the pastures in our country shows that the stage of reclamation only with herbaceous plants has decreased in part. On the other hand, shrub plants act as a microclimate for the growth of other plants with the role they play in the ecological system, and serve as an important element in preventing erosion and protecting biodiversity (Figure 3 ).
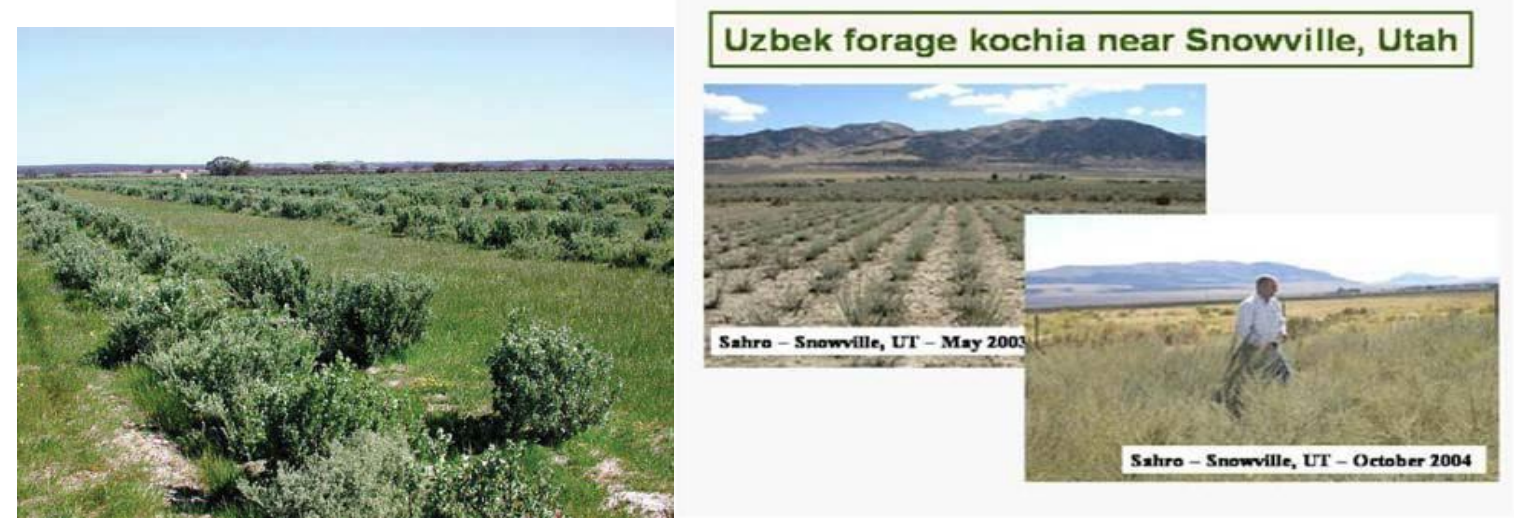

Figure 3

Shrub plants used in pasture breeding in different parts of the world.

Pastures should not be over-grazed, in accordance with grazing power, and generally take half and leave half principle should be followed. Plant residues not only protect the soil against wind and water erosion, but also making soil more humid and facilitates germination and extraction. The determined grazing season must be followed. In order to prevent erosion and to protect the vegetation, the alternately/rotated grazing system should be applied and to avoid the over grazing. With continuous grazing of the animals in the pastures, it is seen that the areas crushed by the animalsand places with no plants are increased. These places, which seem to be insignificant in the early stages, gradually grow and form gullies due to wind erosion,

On the other hand, it should be ensured that the seeds meet the soil in the pastures where it is needed for the renewal of the seeds of pasture plants in the summer season. The number of suitable animals may vary depending on appropriate climate and soil conditions. When these rules are followed, the weak and degraded pasture stage in Figure 4 is not come out and there is no erosion and dust transportation. In the destruction of the pasture, the decrease of invasive plants is the last stage of deterioration, after which the vegetation becomes sparse and cannot protect the soil. In this circuit, erosion has accelerated very rapidly. The soil is significantly lost. Another reason that increases the erosion in the pastures is that some grass and shrub plants with soil-retaining properties are removed and used as firewood (Akalan \& Dogan 1988, Altin et al 2005).

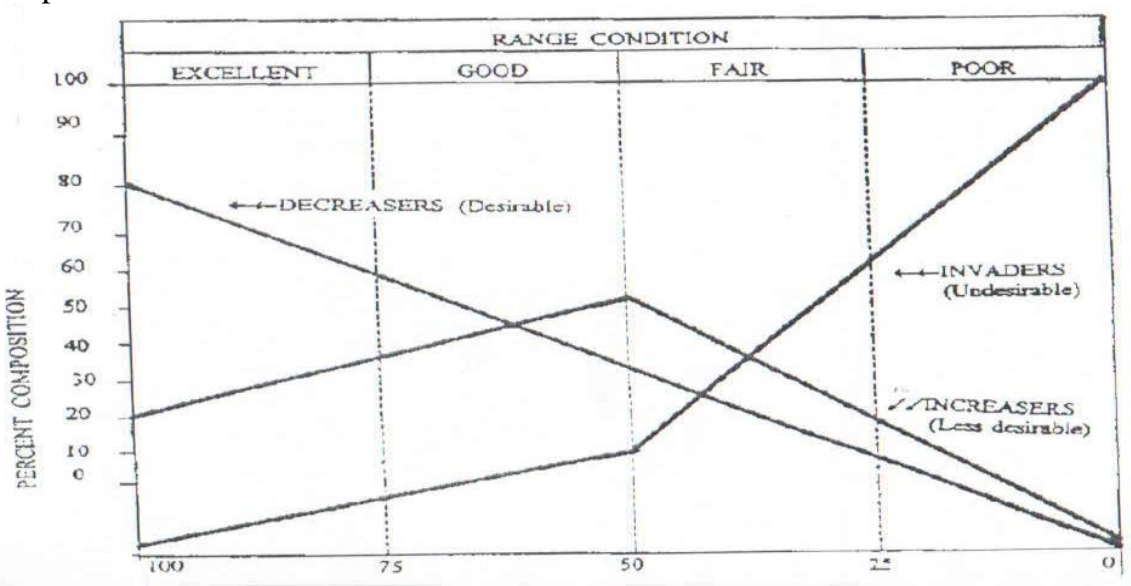

Figure 4

Changes in plant groups according to pasture conditions (Anonymous 2018). 


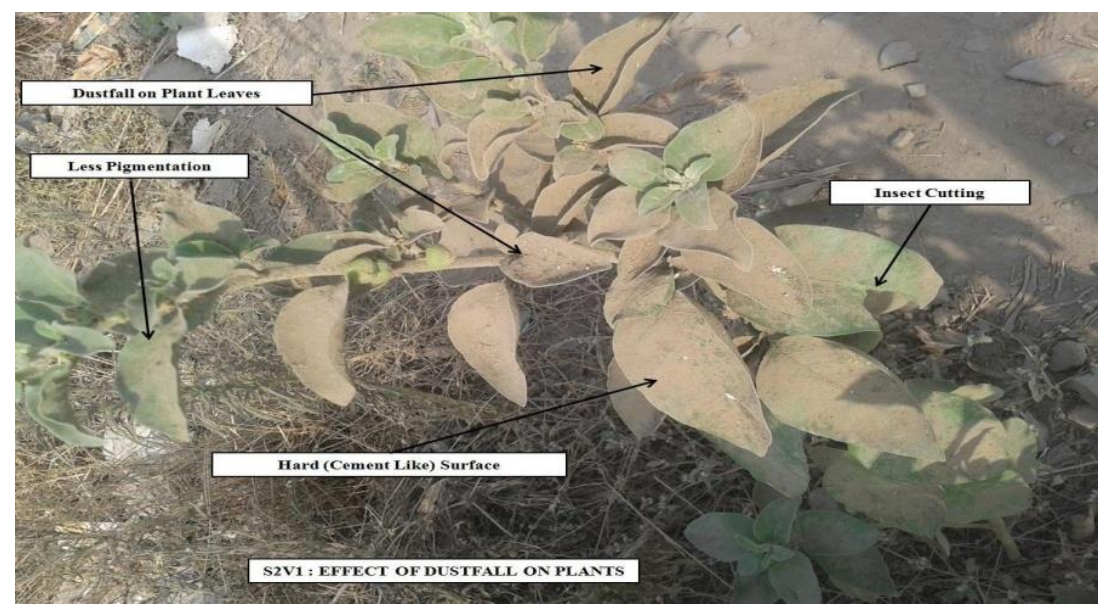

Figure 5

Effect of dust on plant (Supe \& Gawande 2013).

Negative effects of transported dust on plants; when the dust particles that are deposited on the plants cover the surface of the leaves, they can prevent the vital functions of plants such as photosynthesis and transpiration. (Andiç 1984, Supe \& Gawande, 2013). This effect is more severe if the size of the dust particles is small (Bağc1 \& Şengün 2012). It can affect the yield and quality negatively. The other harm to the plants of the dust is that it can be abrasive on the plant surfaces, which is related to the nature of the transported dust. In the dry areas, the dust may adversely affect the water transfer to the plant due to its moisture-absorbing feature (Figure 5).

\section{Harm of Dust to Pasture Animals}

Inorganic dust tend to accumulate in the lung. Dusts, which are at risk of forming fibrosis (hardening of the lung tissue), cause chronic lung diseases by creating a textural disorder. Inhalable dusts are the group of dust that enters the respiratory tract and reaches the alveoli for their size. These dusts are the biggest danger for the disease in the lungs.
Air currents can sweep the mineral particles in the soil and carries to very remote areas. The livings that breathe mineral dusts suspended in the air into the lungs for a certain time are at risk of becoming ill after a while. Research on the respiratory tract and allergic effects of the dusts on animals should be increased. The structures of the transported dusts are important for influencing the animals, and researches about the damages of the dusts type to animals and tolerance limits are needed. Unfortunately, there is very little research on the veterinary issues(on cattle and livestock) of the carried dusts (Lillie 1972).

It is stated that it can be be caused by the feeds/fooders that are affected by them and by the licking of the body hair that holds them rather than not direct effcets of dust or air pollutants damage to the animals in natural pasture areas. Another reason for these types of dust and air pollutants caused low yield in animals is that low quality and taste differences in the herbs and feeds/fodder and also these fodder and herbs are consumed in small amounts by animals. Naturally, this causes decreases in animal welfare and productivity (Lillie 1972).

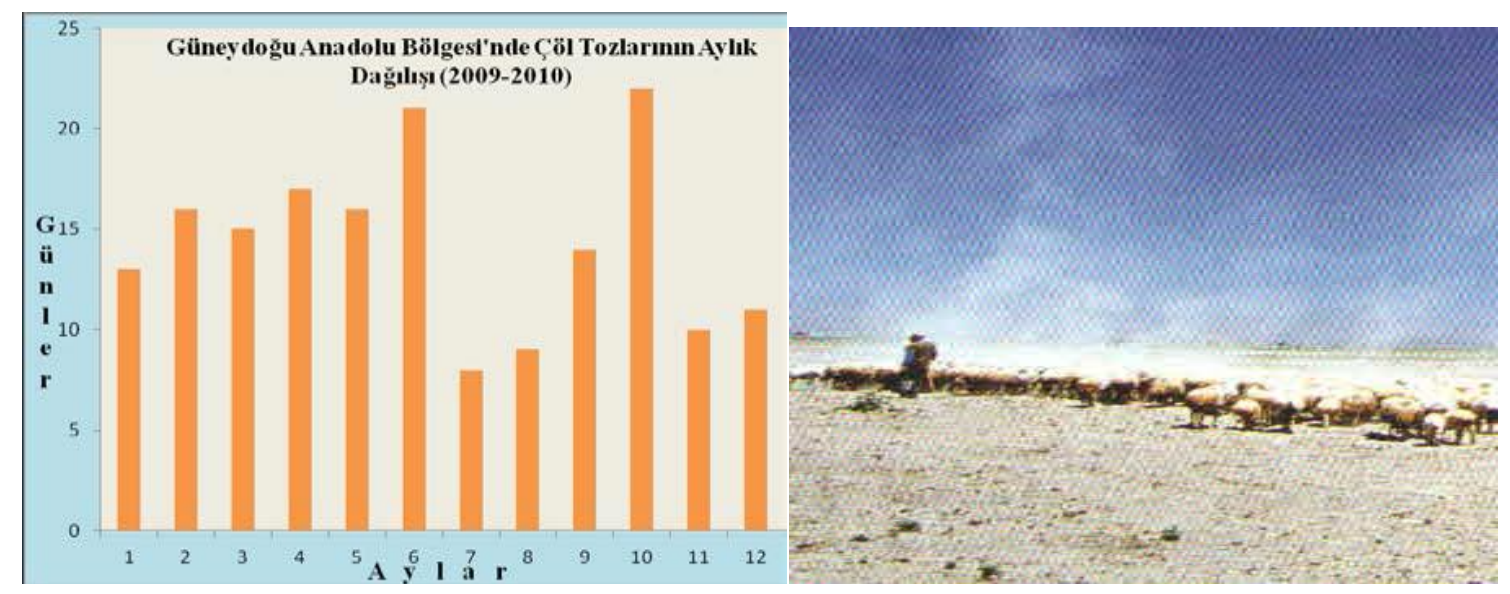

Figure 6

Annual distribution of desert dust in Eastern Anatolia (Şengün \& Kıranşan 2013). 
As seen in Figure 6, the times when most of the desert dusts are present are the times when animals are most in the pasture in terms of grazing season. As dust storms are physically damaging during dust storms and also microorganisms are transported from one region to another, or even from one continent to another. It is also among the results of the studies that desert dusts have spread some of the epidemic diseases in the world (Bağcı \& Şengün 2012). In addition, dusts make the administration of animals difficult.

\section{The Benefit of Desert Dust in Plant Production?}

Some of the studies published on the desert dust in some regions and plants depending on the content of desert dusts, it can be useful for plant and nutritious plants such as agricultural fertilizers (Bagci \& Sengün 2012). This can happen is usually where the soil is inefficient and the precipitation is abundant and regular. There is no dust on the plant for a long time, the dust will reach the soil with rain, the negativity of the dust is eliminated.

\section{Conclusions and Recommendations}

It is possible to protect people from dusty environment by providing personal dust masks for short-term dust protection, but this is not possible for farm animals fed in the open air under pasture conditions. It is therefore feasible that in these places where individual protection is not possible, collective protection of land or grazing animals is feasible. The most effective and lasting method is prevention at source. In other words, it is best to take necessary measures in the source of erosion or dust. If this cannot be performed for various reasons (due to physical or legal management and authority limits or material difficulties), measures should be taken to reduce the negative effects of the dust.

Due to the destruction in a significant part of the arid pastures where our country is insufficient rainfall, it is not now possible to reclaim the areas by vegetating or planting of herbacous plants. In pasture amelioration, shrub or semi-shrub plant formations which have a value of feed with wind screen and protect their herbaceous plants from adverse conditions, should/must be considered additionallyto prevent the erosion or minimize the damages of the dust that can be transported, increase the weed yield and grazing time, facilitate the grazing and management of the animals. Successful examples of these practices are seen with similar or more difficult ecological conditions in different parts of the world. It is necessary to prioritize the construction of wind break screen, which prevents the transportation of the seeds and soil to be planted and prevent the plants from being affected negatively from the wind and dust transportation after the emergence of the plants in reclamation areas where wind erosion is dominating. Particularly in the form of shrubs or semishrub formation can be planted in instead of seed as well, in order to partially prevent damage after sensitive output. There are successful examples in our country and in the world (Figure 7).

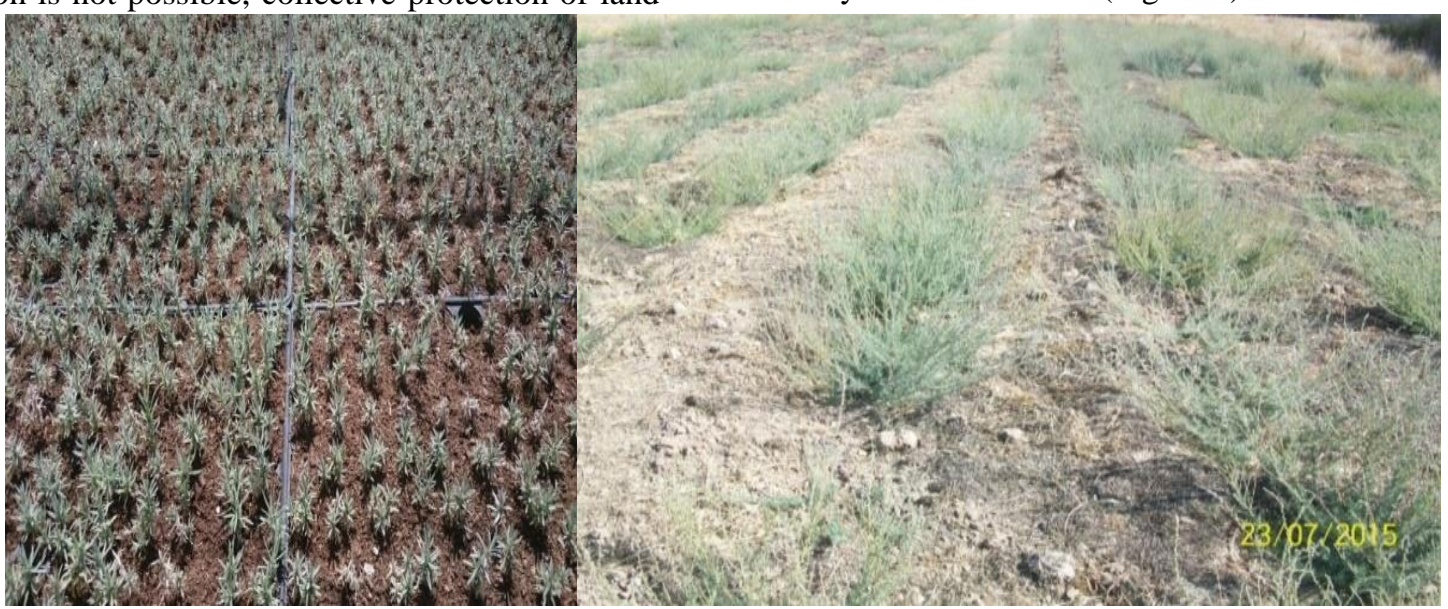

Figure 7

Semi-shrub Bozkır Otu grown in the greenhouse and planted to pasture (Kochia prostrata) (Org.).

Wind protected meadows positively affect the health and efficiency of animals. During the warmer times of the day. Animals which are resting under the trees and resting in the shade increase the milk yield. Unprotected pastures are affected by all kinds of climatic conditions (Altin et al 2005, Avc1 et al 2015).The protection of grazing animals from wind and dust is also important in this respect.

In our country, similar or similar issues (such as erosion and pasture improvement) working together ensure more efficiently and quickly possibilityto achieve the goal. Moreover, the sustainability of the results of the studies depends on concious user and existence of legally regulated organizations.

\section{Acknowledgements}

This paper had been prepared from Oral presentation at the $6^{\text {st }}$ International Workshop on Sand and Dust Stroms to be held in İstanbul/ Turkey, on 12-15 November 2018 . 


\section{References}

Acar R (2017). The new Methods could be applied in Rangeland Improvemnt in Central Anatolian. Tarim TR Dergisi. S:20: 22-28, (In: Turkish).

Acar R, Dursun Ş (2010). Vegetative methods to prevent wind erosion in central Anatolia region. International Engineering Conference on Hot Arid Region. 167-170. Al-Ahsa, KSA

Abalı İ, Taysun A, Doğan O, Çanga M, Önmez O (1986). The Guide Action be Taken and Occuring Wind Erosion in Central Anatolian Region. Köy Hizmetleri Gen. Müd. Yayın no:54. Ankara (In: Turkish).

Akalan İ, Doğan O (1988). The Relationship Between Meadow, Pasture Forage Crops And Soil And Erosion, Köy Hizmetleri Gen. Müd. Yayın no:135. Ankara (In: Turkish).

Altın M, Gökkuş A, Koç A (2005). The Improvement of Meadow and Rangeland. T.C. Tarım ve Köy Işleri Bakanlı̆̆l. Ankara (In: Turkish).

Andiç C (1984). Agricultural Ecology. Atatürk Üniversitesi, Ziraat Fakültesi, Erzurum (In: Turkish).

Anonymous (2012). The Dust Management, The Dust Management Technology, www.martın-eng.com.tr (In: Turkish).

Anonymous (2016). Guide to combating dust in agricultural holdings No 1. Çalışma ve Sosyal Güvenlik Bakanlığı. İş Sağlığı ve Güvenlik Genel Müd. Ankara (In: Turkish).

Anonymous (2018). Degree of utilization and livestock production. www.fao.org/docrep

Anthoni JF (2000). ww.seafriends.org.nz/enviro/soil/erosion.

Avcı H, Gözükara M, Altaş Y, Küçükkaya İ, Doğan O, Orhan C, Keş A, Yıldırım H, Coşkun M, Temiz M, Şahin S, Şahin Ö, Fidan B, Çakıroğlu İ, Tüfekçioğlu U, Karaçorlu N, Bulut İ, Odabaşı YB, Sönmez M
F (2015). Guidance on Considerations to be Considered in Erosion and Flood Control Practices. T.C. Orman ve Su İşleri Bakanlığı. Çöllleşme ve Erozyonla Mücadele Gen. Müd. Ankara (In: Turkish).

Bağc1 HR, Şengün MT (2012). Effects of Desert Powders on Human Environment and Plants, Marmara Coğrafya Dergisi. S.24:409-433.İstanbul (In: Turkish).

Birand H (1968). Chats with Hawthorn Tree. Ongun Kardeşler Matbaası. Ankara (In: Turkish).

Demiryürek M, Okur M, Taysun A (2007). The Effects of Wind-Moving Sediment Amount and Height on the Erosion Field in Karapinar Wind Erosion and the Seasonal Effect on the Relationship between Soil Properties and Dry Aggregates. Project Final Report. Toprak ve Su Kaynakları Arş. Müd. Konya (In: Turkish).

Gündüz İ (1980). Karapinar in all aspects. Karapinar Municipality Publications, Kuzucular Ofset. Konya (In: Turkish).

Lillue RJ (1972). Air Pollutants Affecting The Performance of Domestic Animals. Agriculture Handbook No:380. Agriculturel Research Service. US Department of Agriculture. DC Washington.

Mücevher O, Acar R, Dursun Ş (2016). Types of Trees that can be used in Wind Curtains in Field Covers and Pastures in Aggregation of Agricultural Lands Türktarım Dergisi. S.230:44-47.Ankara (In: Turkish).

Supe GN, Gawande SM. 2013. Effects of Dustfall on Vegetation. Int. J. of Science and Rese$\operatorname{arch} .6(14): 2184$.

Şengün MT, Kıranşan K (2013). The Effect of Desert Powders on Air Quality in Southeastern Anatolia Region, Türk Coğrafya Dergisi. S.59 : 59-68. İstanbul (In: Turkish). 